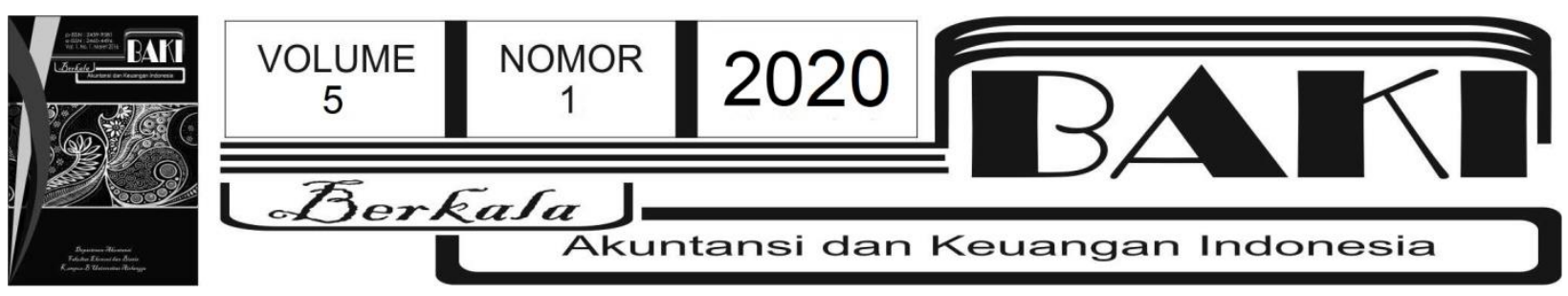

\title{
PENGARUH RASIO KEUANGAN TERHADAP PERTUMBUHAN LABA PADA PERUSAHAAN MAKANAN DAN MINUMAN DI BEI
}

\author{
Kharisma Aulia Dianitha ${ }^{1 a}$ \\ Endang Masitoh ${ }^{1}$ \\ Purnama Siddi ${ }^{1}$
}

${ }^{1}$ Universitas Islam Batik Surakarta

acorresponding author: aulia.kharisma020698@gmail.com

\begin{tabular}{|c|c|}
\hline INFO ARTIKEL & $A B S T R A C T$ \\
\hline $\begin{array}{l}\text { Histori Artikel: } \\
\text { Tanggal Masuk } 7 \text { Januari } \\
2020 \\
\text { Tanggal Diterima } 30 \text { Maret } \\
2020 \\
\text { Tersedia Online } 15 \text { Mei } 2020\end{array}$ & \multirow{2}{*}{$\begin{array}{l}\text { This study aims to examine the effect of Quick Ratio, Debt to Equity } \\
\text { Ratio, Net Profit Margin, and Return on Investment on profit growth } \\
\text { on Indonesian public listed food and beverage companies in 2015- } \\
2018 \text {. Multiple linear regression is used to analyze } 12 \text { sample. The } \\
\text { results shows that Quick Ratio, Debt to Equity Ratio, Net Profi } \\
\text { Margin, and Return on Investment have an effect on profit growth } \\
\text { simultaneously with a significant level of <0.05. Meanwhile, Return on } \\
\text { Investment has an effect partially on earnings growth with a } \\
\text { significant level of } 0.009 \text { that means less than }<0,05 \text {. }\end{array}$} \\
\hline $\begin{array}{l}\text { Keywords: } \\
\text { QR, DER, NPM, ROI, } \\
\text { Growth Profits }\end{array}$ & \\
\hline \multirow{2}{*}{$\begin{array}{l}\text { Kata Kunci: } \\
\text { QR, DER, NPM, ROI, } \\
\text { Growth Profits }\end{array}$} & A B S TRAK \\
\hline & $\begin{array}{l}\text { Penelitian ini bertujuan untuk menguji dan menganalisis pengaruh } \\
\text { Quick Ratio, Debt to Equity Ratio, Net Profit Margin, dan Return On } \\
\text { Investment terhadap Pertumbuhan Laba pada Perusahaan Makanan } \\
\text { dan Minuman yang terdaftar di BEI periode } 2015-2018 \text {. Sampel } \\
\text { pada penelitian ini sebanyak } 12 \text { sampel. Metode analisis data pada } \\
\text { penelitian ini adalah analisis regresi linear berganda. Hasil dari } \\
\text { penelitian ini menunjukkan bahwa secara simultan quick ratio, debt to } \\
\text { equity ratio, net profit margin, dan return on investment berpengaruh } \\
\text { terhadap pertumbuhan laba dengan nilai sig }<0,05 \text {. Secara parsial } \\
\text { hanya return on investment yang berpengaruh terhadap pertumbuhan } \\
\text { laba dengan nilai sig. } 0.009 \text { yang artinya kurang dari }<0,05 \text {. }\end{array}$ \\
\hline
\end{tabular}

Berkala Akuntansi dan Keuangan Indonesia p-ISSN: 2459-9581; e-ISSN 2460-4496 DOI: $10.20473 /$ baki.v5i1.17172

Open access under Creative Common Attribution-Non Commercial-Share A like 4.0 International Licence (CC-BY-NC-SA) @D@ @ 


\section{Pendahuluan}

Suatu perusahaan pada umumnya didirikan dengan tujuan untuk mendapatkan laba. Tujuan perusahaan ada 2 yaitu tujuan komersil dan tujuan sosial (Siagian, 2005). Tujuan komersil atau profit oriented adalah tujuan perusahaan untuk memperoleh laba. Laba yang di peroleh perusahaan diharapkan meningkat dari satu periode ke periode selanjutnya. Pertumbuhan laba merupakan perubahan persentase kenaikan laba yang diperoleh perusahaan. Pertumbuhan laba yang baik mengisyaratkan bahwa perusahaan mempunyai keuangan yang baik, yang pada akhirnya akan meningkatkan nilai perusahaan karena besarnya deviden yang akan dibayar di masa akan datang sangat bergantung pada kondisi perusahaan (Taruh, 2012). Pada penelitian Khalidazia dan Muda (2014) menjelaskan bahwa Quick Ratio berpengaruh secara simultan terhadap pertumbuhan laba, tetapi dalam penelitian tersebut juga disebutkan bahwa Quick Ratio secara parsial tidak berpengaruh tehadap pertumbuhan laba.

Menurut penelitian Sayekti dan Saputra (2015) mengungkapkan bahwa Debt to Equity Ratio berpengaruh secara simultan terhadap pertumbuhan laba. Debt to Eqity Ratio digunakan untuk menunjukkan seberapa besar modal perusahaan digunakan untuk jaminan utang. Dengan nilai utang yang tinggi, maka laba yang dihasilkan akan berkurang. Oleh karena itu, rasio solvabilitas atau leverage akan mempengaruhi pertumbuhan laba. Namun berbeda dengan penelitian Andriyani (2015) yang memiliki hasil bahwa Debt to Equity Ratio tidak berpengaruh terhadap pertumbuhan laba.

Penelitian Silalahi et al., (2019) menunjukkan bahwa Net Profit Margin dan Return On Investment berpengaruh secara simultan terhadap pertumbuhan laba. Sedangkan penelitian Napitupulu (2019) menyatakan bahwa Net Profit Margin dan Return On Investment tidak berpengaruh terhadap pertumbuhan laba. Penelitian ini menjadi penting untuk dilakukan karena laba merupakan prestasi perusahaan dalam menunjukkan operasionalnya. Sehingga dengan adanya pertumbuhan laba maka manajemen dapat menentukan kinerja perusahaan untuk periode selanjutnya.

Gap research pada penelitian ini ditemukan pada variabel Quick Ratio, Debt to Equity Ratio, Net Profit Margin dan Return on Investment, karena terdapat perbedaan hasil penelitian. Gap research ini menjadi celah untuk meneliti kembali dengan tujuan memperjelas temuan temuan penelitian sebelumnya. Berdasarkan latar belakang tersebut maka peneliti tertarik mengambil judul penelitian "Pengaruh Rasio Keuangan terhadap Pertumbuhan Laba pada Perusahaan Makanan dan Minuman di Bursa Efek Indonesia".

Berdasarkan latar belakang tersebut, perumusan masalah dalam penelitian ini adalah: (1) Bagaimana pengaruh Quick Ratio terhadap pertumbuhan laba? (2) Bagaimana pengaruh Debt 
to Equity Ratio terhadap pertumbuhan laba? (3) Bagaimana pengaruh Net Profit Margin terhadap pertumbuhan laba? (4) Bagaimana pengaruh Return On Investment terhadap pertumbuhan laba? Tujuan dari penelitian ini adalah (1) Untuk mengetahui dan menganalisis pengaruh Quick Ratio terhadap pertumbuhan laba. (2) Untuk mengetahui dan menganalisis pengaruh Debt to Equity Ratio terhadap pertumbuhan laba. (3) Untuk mengetahui dan menganalisis pengaruh Net Profit Margin terhadap pertumbuhan laba. (4) Untuk mengetahui dan menganalisis pengaruh Return On Investment terhadap pertumbuhan laba. Manfaat penelitian bagi akademisi yaitu: Sebagai bahan referensi bagi mahasiswa yang akan melakukan penelitian mengenai pengaruh rasio keuangan terhadap pertumbuhan laba. Manfaat bagi Praktisi yaitu: Membantu para calon investor untuk berinvestasi pada perusahaan dilihat dari pertumbuhan labanya.

\section{Tinjauan Pustaka}

Berikut ini penjelasan mengenai variabel pada penelitian ini, penelitian ini menggunakan 4 variabel independen dan 1 variabel dependen.

\subsection{Quick Ratio}

Menurut Hanafi dan Halim (2016:76) rasio cepat dapat mengukur kemampuan memenuhi utang jangka pendeknya dengan menggunakan aktiva lancarnya (aktiva yang akan berubah menjadi kas dalam waktu satu tahun atau satu tahun siklus bisnis).

$$
\mathrm{QR}=\frac{\text { Aktiva Lancar }- \text { Persediaan }}{\text { Hutang Lancar }}
$$

\subsection{Debt to Equity Ratio}

Menurut Mardi et al., (2012), Debt to Equity Ratio adalah rasio yang menggambarkan sampai sejauh mana modal pemilik dapat menutupi utang-utang kepada pihak luar.

$$
\text { DER }=\frac{\text { Total Hutang }}{\text { Ekuitas }}
$$

\subsection{Net Profit Margin}

Manullang (2016) mendefinisikan, NPM adalah sebuah angka persentase yang menunjukkan hubungan antara keuntungan bersih perusahaan dengan total penjualan. 
Margin laba bersih yaitu ukuran keuntungan dengan membandingkan antara laba setelah bunga dan pajak dibandingkan dengan penjualan. Rasio ini berguna untuk menunjukkan pendapatan bersih perusahaan atas penjualan.

$$
\text { NPM }=\frac{\text { Laba Bersih Setelah Pajak }}{\text { Penjulan }} \times 100 \%
$$

\subsection{Return On Investment}

Menurut Mardi et al., (2012) Return On Invesment merupakan rasio yang menunjukkan kemampuan perusahaan untuk menghasilkan keuntungan yang akan digunakan untuk menutup investasi yang dikeluarkan.

$$
\mathrm{ROI}=\frac{\text { Laba Bersih }}{\text { Total Aktiva }}
$$

\subsection{Pertumbuhan Laba}

Harahap (2012) mendefinisikan, "Pengertian laba secara operasional adalah perbedaan antara pendapatan yang direalisasi yang muncul dari transaksi selama satu periode dengan biaya yang berkaitan dengan pendapatan tersebut".

Pertumbuhan Laba = Laba bersih tahun ini - Laba bersih tahun lalu Laba bersih tahun lalu

\section{Gambar 1. Kerangka Pemikiran}

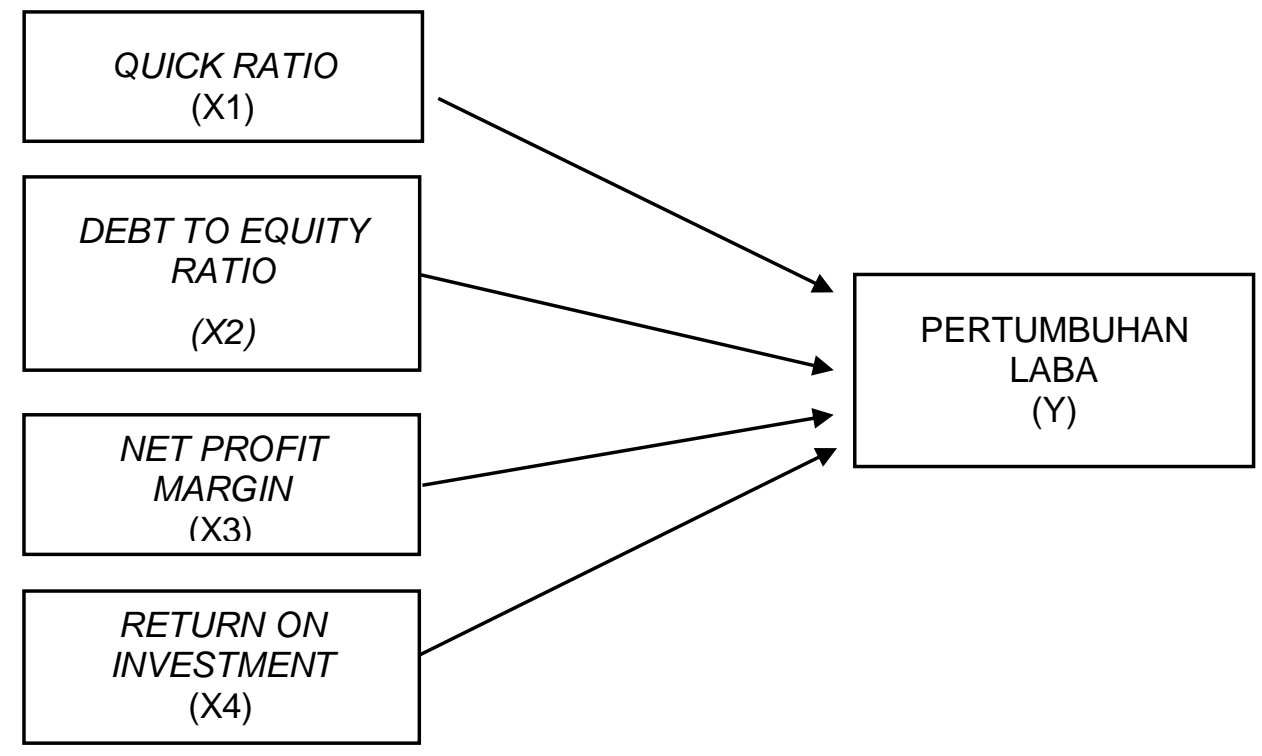




\subsection{Pengembangan Hipotesis}

\subsubsection{Quick Ratio terhadap Pertumbuhan Laba}

Quick ratio merupakan rasio yang menunjukkan kemampuan perusahaan dalam memenuhi atau membayar kewajiban atau hutang lancar dengan aktiva lancar tanpa memperhitungkan nilai perusahaan (Halim, 2009). Penelitian Wahyuni et al., (2017) yang menunjukkan hasil bahwa Quick Ratio, Debt Equity Ratio, Inventory Turnover, Net Profit Margin berpengaruh secara simultan terhadap pertumbuhan laba. Berdasarkan pemikiran tersebut, dapat diturunkan hipotesis sebagai berikut:

H1: Quick Ratio berpengaruh terhadap pertumbuhan laba.

\subsubsection{Debt to Equity Ratio terhadap Pertumbuhan Laba}

Debt to equity ratio merupakan rasio yang digunakan untuk menilai utang dengan equitas. Debt to equity ratio yang rendah berarti semakin sedikit aktiva perusahaan yang dibiayai oleh hutang serta semakin kecil beban bunga yang harus dibayar sehingga laba perusahaan akan meningkat. Penelitian Mahendra (2017) yang menunjukkan hasil bahwa Current Ratio, Return On Equity, dan Debt to Equity Ratio berpengaruh terhadap pertumbuhan laba. Berdasarkan pemikiran tersebut, dapat diturunkan hipotesis sebagai berikut:

H2: Debt to Equity Ratio berpengaruh terhadap pertumbuhan laba.

\subsubsection{Net Profit Margin terhadap Pertumbuhan Laba}

Manullang (2016) mendefinisikan, NPM adalah sebuah angka persentase yang menunjukkan hubungan antara keuntungan bersih perusahaan dengan total penjualan. Penelitian Ade et al., (2018) yang menunjukkan hasil bahwa Net Profit Margin berpengaruh terhadap pertumbuhan laba. Berdasarkan pemikiran tersebut, dapat diturunkan hipotesis sebagai berikut:

H3: Net Profit Margin berpengaruh terhadap pertumbuhan laba.

\subsubsection{Return On Investment terhadap Pertumbuhan Laba}

Penelitian Silalahi (2019) mengungkapkan bahwa koefisien regresi variabel ROI 
sebesar 0,551 artinya setiap terjadi penambahan satuan unit ROI (X4) maka akan terjadi peningkatan Pertumbuhan Laba sebesar 0,551. Hal ini menunjukkan Return on Investment (ROI) berpengaruh secara simultan terhadap Pertumbuhan Laba. Berdasarkan pemikiran tersebut, dapat diturunkan hipotesis sebagai berikut:

H4: Return On Investment berpengaruh terhadap pertumbuhan laba.

\section{Metodologi Penelitian}

\subsection{Pengukuran dan Definisi Operasional}

Dalam penelitian ini yang berperan sebagai variabel dependen adalah pertumbuhan laba Variabel dependen adalah variabel yang dipengaruhi, akibat dari adanya variabel bebas. Dalam bahasa Indonesia sering juga disebut variabel terikat. Variabel terikat merupakan variabel yang dipengaruhi atau menjadi akibat, karena adanya variabel bebas (Sugiyono, 2013:61). Variabel dependen yang digunakan dalam penelitian ini adalah Pertumbuhan Laba. Pertumbuhan laba dapat dihitung dengan cara mencari laba bersih tahun ini dikurangi laba bersih tahun lalu kemudian dibagi dengan laba bersih tahun lalu.

Selanjutnya terdapat empat variabel independen pada penelitian ini, di antaranya adalah: (1) Quick Ratio: Menurut Hanafi dan Halim (2016:76) rasio cepat dapat mengukur kemampuan memenuhi utang jangka pendeknya dengan menggunakan aktiva lancarnya (aktiva yang akan berubah menjadi kas dalam waktu satu tahun atau satu tahun siklus bisnis). Untuk mencari quick ratio, diukur dengan total aktiva lancar, kemudian dikurangi dengan nilai sediaan. Setelah itu dibagi dengan hutang lancar. (2) Debt to Equity Ratio: Menurut Mardi et al., (2012), Debt to Equity Ratio adalah rasio yang menggambarkan sampai sejauh mana modal pemilik dapat menutupi utang-utang kepada pihak luar. Untuk mencari Debt to Equity Ratio, diukur dengan total hutang, kemudian dibagi dengan ekuitas/modal. (3) Net Profit Margin: Manullang (2016) mendefinisikan, NPM adalah sebuah angka persentase yang menunjukkan hubungan antara keuntungan bersih perusahaan dengan total penjualan. Margin laba bersih yaitu ukuran keuntungan dengan membandingkan antara laba setelah bunga dan pajak dibandingkan dengan penjualan. Rasio ini berguna untuk menunjukkan pendapatan bersih perusahaan atas penjualan. (4) Return On Investment: Menurut Mardi et al., (2012) Return On Invesment merupakan rasio yang menunjukkan kemampuan perusahaan untuk menghasilkan keuntungan yang akan digunakan untuk menutup investasi yang dikeluarkan. Return On Investment merupakan ukuran efisiensi penggunaan modal di dalam suatu perusahaan. Untuk mencari return on investment, dapat diukur dengan mencari laba bersih lalu dibagi dengan total asset. 


\subsection{Metode Analisis Data}

Jenis penelitian ini menggunakan pendekatan kuantitatif, yaitu untuk mencari apakah terdapat pengaruh yang signifikan antara variabel independen dengan variabel dependen pada subyek penelitian yang khusus. Pendekatan penelitian yang bersifat obyektif, mencakup pengumpulan data dan analisis data kuantitatif serta menggunakan metode pengujian statistik. Dalam penelitian ini data yang digunakan adalah data sekunder yang diambil dari laporan keuangan perusahaan Manufaktur (Sub sektor Makanan dan Minuman) dari Bursa Efek Indonesia (BEI) selama periode 2015-2018. Populasi dalam penelitian ini adalah seluruh perusahaan manufaktur (sub sektor makanan dan minuman) yang terdaftar Bursa Efek Indonesia (BEI) selama periode 2015-2018.

Sedangkan sampel adalah bagian atau wakil populasi yang memiliki karakteristik yang sama dengan populasinya. Dalam penelitian ini menggunakan 12 sampel perusahaan manufaktur (sub sektor makanan dan minuman) yang diambil dengan menggunakan metode purposive sampling. Sampling purposive adalah teknik penentuan sampel dengan menggunakan pertimbangan atau kriteria tertentu (Sugiyono, 2013: 85). Adapun kriteria sampel pada penelitian ini adalah: (1) Perusahaan manufaktur yang terdaftar di Bursa Efek Indonesia yang tidak pernah suspend (menghentikan atau mengnonaktifkan sesuatu baik itu bersifat sementara atau permanen) selama periode penelitian. (2) Perusahaan manufaktur yang terdaftar di Bursa Efek Indonesia yang memiliki laba dan tidak mengalami rugi selama periode penelitian. (3) Perusahaan manufaktur yang terdaftar di Bursa Efek Indonesia yang secara berturut-turut selalu mempublikasikan data yang dibutuhkan setiap periode penelitian. (4) Memiliki data lengkap yang berkaitan dengan variabel dalam penelitian ini.

Tabel 1. Purposive Sampling

\begin{tabular}{|l|l|c|}
\hline No. & \multicolumn{1}{|c|}{ Kriteria } & Jumlah \\
\hline 1 & $\begin{array}{l}\text { Perusahaan Sub-sektor makanan dan minuman yang terdaftar di BEI } \\
2015-2018\end{array}$ & 26 \\
\hline 2 & Perusahaan yang mengalami kerugian & $(5)$ \\
\hline 3 & Perusahaan yang tidak mempublikasi data di BEI 2015-2018 & $(8)$ \\
\hline 4 & Perusahaan yang mempublikasi data menggunakan mata uang asing & $(1)$ \\
\hline 5 & Perusahaan yang menjadi sampel penelitian & 12 \\
\hline & Jumlah data yang diolah (4 tahun) & 48 \\
\hline
\end{tabular}


Pada penelitian ini, peneliti akan menggunakan metode analisis regresi linear berganda untuk mengetahui ada atau tidaknya pengaruh antara variabel independen terhadap variabel dependen. Analisis Regresi Linier Berganda

1) Model Regresi

$$
Y^{\prime}=a+b_{1} X_{1}+b_{2} X_{2}+b_{3} X_{3}+b_{4} X_{4}+e
$$

Keterangan:

Y: Pertumbuhan Laba

$\begin{array}{ll}\mathrm{a} & : \text { Konstanta } \\ \mathrm{X}_{1} & : \text { QR } \\ \mathrm{X}_{2} & : \text { DER } \\ \mathrm{X}_{3} & : \text { NPM } \\ \mathrm{X}_{4} & : \text { ROI } \\ \mathrm{e} & : \text { error }\end{array}$

\section{Analisis dan Pembahasan}

\subsection{Statistik Deskriptif}

Tabel 2. Analisis Deskriptif

Statistics

\begin{tabular}{|l|r|r|r|r|r|}
\hline & QR & DER & NPM & ROI & $\begin{array}{l}\text { PERTUMBU } \\
\text { HAN LABA }\end{array}$ \\
\hline N Valid & 48 & 48 & 48 & 48 & 48 \\
Missing & 0 & 0 & 0 & 0 & 0 \\
Mean & .0133 & .7700 & .0656 & .0885 & .1452 \\
Median & .0100 & .6950 & .0650 & .0750 & .1050 \\
Mode & .01 & .11 & .03 & $.04^{\mathrm{a}}$ & .15 \\
Std. Deviation & .00930 & .48482 & .04115 & .05497 & .42571 \\
Minimum & .00 & .09 & .01 & .01 & -.57 \\
Maximum & .04 & 1.77 & .16 & .22 & 1.60 \\
\hline
\end{tabular}

a. Multiple modes exist. The smallest value is shown 
Pada tabel diatas dapat diketahui bahwa: Nilai mean dari variabel Quick Ratio (QR) sebesar 0,01, untuk variabel Debt to Equty Ratio (DER) sebesar 0,77, untuk variabel Net Profit Margin (NPM) sebasar 0,65, untuk variabel Return On Investment (ROI) sebesar 0,88, dan untuk variabel pertumbuhan laba sebesar 0,14. Nilai median dari variabel Quick Ratio (QR) sebesar 0,01, untuk variabel Debt to Equty Ratio (DER) sebesar 0,69, untuk variabel Net Profit Margin (NPM) sebasar 0,65, untuk variabel Return On Investment (ROI) sebesar 0,75, dan untuk variabel pertumbuhan laba sebesar 0,10 . Nilai modus dari variabel Quick Ratio (QR) sebesar 0,01, untuk variabel Debt to Equty Ratio (DER) sebesar 0,11, untuk variabel Net Profit Margin (NPM) sebasar 0,03, untuk variabel Return On Investment (ROI) sebesar 0,04, dan untuk variabel pertumbuhan laba sebesar 0,15. Untuk variabel $Q R$ memiliki nilai minimum 0,00 dan maksimum 0,04, untuk variabel DER memiliki nilai minimum 0,09 dan maksimum 1,77, untuk variabel NPM memiliki nilai minimum 0,01 dan maksimum 0,16 , untuk variabel $\mathrm{ROI}$ memiliki nilai minimum 0,01 dan maksimum 0,22 , dan variabel pertumbuhan laba memiliki nilai minimum -0,57 dan maksimum 1,60.

\subsection{Uji Asumsi Klasik}

\subsubsection{Uji Normalitas}

Tabel 3

Uji Normalitas

\begin{tabular}{llll}
\hline Variabel & Sig & Standar & Keterangan \\
\hline Residual & 0,199 & $>0,05$ & Terdistribusi Normal \\
\hline
\end{tabular}

Sumber: Lampiran

Berdasarkan tabel 3 tersebut menunjukkan bahwa angka signifikansi atau Asymp. Sig. (2tailed) yang diperoleh sebesar 0,199 dimana nilai ini melebihi 0,05 (dalam kasus ini menggunakan taraf signifikansi sebesar $5 \%$ atau $\alpha=5 \%$ ) sehingga residual mengikuti distribusi normal. Variabel Quick Ratio, Debt to Equity Ratio, Net Profit Margin, Return On Investment, dan Pertumbuhan Laba berdistribusi normal.

\subsubsection{Uji Multikolinearitas}

Berdasarkan table 4 nilai tolerance tidak ada yang bernilai dibawah 0,1 dan nilai Variance Inflation Factor (VIF) menunjukkan nilai yang sama yaitu tidak ada satu variabel yang memiliki nilai VIF lebih besar dari 10. Hal ini dapat dilihat dari nilai Tolerance variabel Quick Ratio, Debt to Equity Ratio, Net Profit Margin, dan Return On Investment sebesar 
0,734, 0,714, 0,400, 0,410. Dari hasil pengujian diperoleh nilai Variance Inflation Factor (VIF) untuk variabel Quick Ratio sebesar 1,363, variabel Debt to Equity Ratio sebesar 1,401, variabel Net Profit Margin sebesar 2,502 dan variabel Return On Investment sebesar 2,437. Dengan demikian dapat disimpulkan dalam penelitian ini tidak terjadi multikolinieritas.

Tabel 4

Uji Multikolinieritas

\begin{tabular}{lccccc}
\hline \multicolumn{1}{c}{ Variabel } & Tolerance & Syarat & VIF & Syarat & Keputusan \\
\hline Quick Ratio & 0,734 & $>0,1$ & 1,363 & $<10$ & $\begin{array}{c}\text { Tidak terjadi } \\
\text { multikolinieritas }\end{array}$ \\
\hline Debt to Equity Ratio & 0,714 & $>0,1$ & 1,401 & $<10$ & $\begin{array}{c}\text { Tidak terjadi } \\
\text { multikolinieritas }\end{array}$ \\
\hline Net Profit Margin & 0,400 & $>0,1$ & 2,502 & $<10$ & $\begin{array}{c}\text { Tidak terjadi } \\
\text { multikolinieritas }\end{array}$ \\
\hline $\begin{array}{l}\text { Return On } \\
\text { Investment }\end{array}$ & 0,410 & $>0,1$ & 2,437 & $<10$ & $\begin{array}{c}\text { Tidak terjadi } \\
\text { multikolinieritas }\end{array}$
\end{tabular}

Sumber: Lampiran

\subsubsection{Uji Autokorelasi}

Pengukuran autokorelasi dilihat dari unstandardized residual pada tabel 5. Dimana hasil Asymp. Sig harus lebih besar dari a yang ditentukan $(0,05)$. Hasil uji autokorelasi pada data penelitian ini memiliki nilai Asymp. Sig (2-tailed) sebesar 0,058 dimana lebih besar daripada 0,05 yang artinya data tidak terjadi autokorelasi.

Tabel 5

Uji Autokorelasi

\begin{tabular}{llll}
\hline Variabel & Sig & Standar & Keterangan \\
\hline Run Test & 0,058 & $>0,05$ & Tidak Terjadi Autokorelasi \\
\hline
\end{tabular}

Sumber: Lampiran

\subsubsection{Uji Heteroskedastisitas}

Tabel 7 menujukkan nilai sig. masing - masing yaitu Quick Ratio sebesar 0,909, variabel Debt to Equity Ratio sebesar 0,815, variabel Net Profit Margin sebesar 0,495, dan variabel Return On Investment sebesar 0,888. Nilai sig. masing - masing variabel bebas lebih dari $\alpha$ $(0,05)$ yang artinya terbebas dari masalah heterokesdastisitas. 
Tabel 6

Uji Heterokesdastisitas

\begin{tabular}{cccc}
\hline Variabel & Sig & Standar & Keterangan \\
\hline QR & 0,909 & $>0,05$ & Bebas Haterokesdastisitas \\
\hline DER & 0,815 & $>0,05$ & Bebas Heterokesdastisitas \\
\hline NPM & 0,495 & $>0,05$ & Bebas Heterokesdastisitas \\
\hline ROI & 0,888 & $>0,05$ & Bebas Heterokesdastisitas
\end{tabular}

Sumber: Lampiran

\subsection{Uji Hipotesis}

\subsubsection{Uji Regresi}

\section{Tabel 7}

Uji Regresi

\begin{tabular}{c|c}
\hline Model & B \\
\hline (Constant) & $-0,297$ \\
\hline QR & 0,689 \\
\hline DER & 0,250 \\
\hline NPM & $-2,546$ \\
\hline ROI & 4,611 \\
\hline
\end{tabular}

Sumber: Lampiran

Hasil analisis regresi linear berganda diperoleh koefisien untuk variabel bebas $X 1=0,689$, $\mathrm{X} 2=0,250, \mathrm{X} 3=-2,546$, dan $\mathrm{X} 4=4,611$ dengan konstanta sebesar $-0,297$ sehingga model persamaan regresi yang diperoleh adalah:

$\mathrm{Y}=-0,297+0,689 \mathrm{X} 1+0,250 \mathrm{X} 2-2,546 \mathrm{X} 3+4,611 \mathrm{X} 4+\mathrm{e}$

Berdasarkan hasil persamaan regresi diatas, maka dapat dianalisis sebagai berikut:

Variabel quick ratio sebesar 0,689 , debt to equity ratio sebesar 0,250 , net profit margin sebesar -2,546, dan return on investment sebesar 4,611 sedangkan pada constan atau pertumbuhan laba sebesar -0,297. Dengan kata lain tidak ada bias (kesalahan) spesifikasi dalam model yang digunakan dalam analisis empirik.

\subsubsection{Uji F}

Hasil perhitungan dengan menggunakan program SPSS dapat diketahui bahwa f hitung sebesar 18,351 > f tabel 2,822 dengan nilai Sig. 0,000, karena nilai Sig. lebih kecil dari 0,05. Maka Ha diterima dan Ho ditolak. Jadi dapat disimpulkan bahwa ada pengaruh secara bersama 
- sama / simultan antara Quick Ratio, Debt to Equity Ratio, Net Profit Margin, dan Return On Investment terhadap Pertumbuhan Laba.

Tabel 8

Uji F

\begin{tabular}{cccccc}
\hline Hipotesis & $\mathbf{F}_{\text {hitung }}$ & $\mathbf{F}_{\text {tabel }}$ & Sig & Syarat & Keputusan \\
\hline $\mathrm{Ha}$ & 18,351 & 2,822 & 0,000 & 0,05 & Simultan \\
\hline
\end{tabular}

Sumber: Lampiran

\subsubsection{Uji Hipotesis}

Nilai signifikansi $\mathrm{H} 1$ sebesar. 0,927 yang menyatakan bahwa $\mathrm{H} 1$ di tolak dengan hipotesis tidak berpengaruh terhadap pertumbuhan laba. Nilai signifikansi $\mathrm{H} 2$ sebesar 0,092 yang menyatakan bahwa $\mathrm{H} 2$ di tolak dengan hipotesis tidak berpengaruh terhadap pertumbuhan laba. Nilai signifikansi H3 sebesar 0,271 yang menyatakan bahwa H3 di tolak dengan hipotesis tidak berpengaruh terhadap pertumbuhan laba. Nilai signifikansi H4 sebesar 0,009 yang menyatakan bahwa $\mathrm{H} 4$ di terima dengan hipotesis berpengaruh terhadap pertumbuhan laba.

Tabel 9

Uji Hipotesis

\begin{tabular}{lccl}
\hline \multicolumn{1}{c}{ Hipotesis } & Sig & Syarat & Hasil \\
\hline Quick Ratio & 0,927 & $<0,05$ & Ditolak \\
\hline Debt to Equity Ratio & 0,092 & $<0,05$ & Ditolak \\
\hline Net Ptofit Margin & 0,271 & $<0,05$ & Ditolak \\
\hline Return On Investment & 0,009 & $<0,05$ & Diterima \\
\hline
\end{tabular}

Sumber: Lampiran

\subsubsection{Uji Koefisien Determinasi}

Dari tabel 10 angka koefisien determinasi yang dapat dilihat melalui adjusted $\mathrm{R}$ square adalah sebesar 0,649 (64,9\%) yang berarti variabel bebas yaitu Quick Ratio, Debt to Equity Ratio, Net Profit Margin, Return On Investment. Sedangkan 35,1\% dijelaskan oleh variabel lain diluar penelitian. 


\begin{tabular}{cc}
\hline Adjusted R Square & Kesimpulan \\
\hline 0,649 & Berpengaruh sebesar $64,9 \%$ \\
\hline
\end{tabular}

Sumber: Lampiran

\subsection{Pembahasan}

\subsubsection{Pengaruh Quick Ratio terhadap Pertumbuhan Laba}

Hipotesis pertama yang diajukan dalam penelitian ini yaitu variabel Quick Ratio (QR) berpengaruh terhadap pertumbuhan laba. Hasil penelitian yang telah dilakukan menunjukkan bahwa QR memiliki t hitung sebesar 0,092 dan nilai signifikan sebesar 0,927 yang berarti lebih dari 0,05. Hal ini menujukkan bahwa variabel $Q R$ tidak berpengaruh terhadap pertumbuhan laba.

Hasil penelitian ini mendukung penelitian sebelumnya yang dilakukan oleh Oktanto dan Nuryanto (2014) yang menyatakan bahwa tidak terdapat pengaruh antara Quick Ratio terhadap pertumbuhan laba perusahaan. Namun berbeda dengan penelitian Khalidzia dan Iskandar (2014) yang menyatakan bahwa ada pengaruh antara Quick Ratio terhadap pertumbuhan laba. Dengan demikian, maka hipotesis yang menyatakan bahwa variabel Quick Ratio (QR) berpengaruh signifikan terhadap pertumbuhan laba tidak dapat diterima.

\subsubsection{Pengaruh Debt to Equity Ratio terhadap Pertumbuhan Laba}

Hipotesis kedua yang diajukan dalam penelitian ini yaitu variabel Debt to Equity Ratio (DER) berpengaruh terhadap pertumbuhan laba. Hasil dari penelitian ini menunjukkan bahwa Debt to Equity Ratio (DER) memiliki t hitung sebesar 1,722 dan dengan nilai signifikan 0,92 yang berarti lebih besar dari 0,05. Hal ini menujukkan bahwa variabel DER tidak berpengaruh terhadap pertumbuhan laba.

Hasil penelitian ini mendukung penelitian sebelumnya yang dilakukan oleh Indriyanin (2015) yang menyatakan bahwa tidak terdapat pengaruh antara Debt to Equity Ratio terhadap pertumbuhan laba perusahaan. Namun hasil penelitian ini tidak mendukung hasil penelitian dari Himalaya et al., (2017) yang menyatakan bahwa terdapat pengaruh antara Debt to Equity Ratio terhadap pertumbuhan laba. Maka, hipotesis yang menyatakan bahwa variabel Debt to Equity Ratio (DER) berpengaruh terhadap pertumbuhan laba tidak dapat diterima.

\subsubsection{Pengaruh Net Profit Margin terhadap Pertumbuhan Laba}


Hipotesis ketiga yang diajukan dalam penelitian ini yaitu variabel Net Profit Margin (NPM) berpengaruh terhadap pertumbuhan laba. Dari hasil penelitian yang diperoleh, diketahui bahwa Net Profit Margin (NPM) memilikin t hitung sebesar -1,115 dan nilai signifikan sebesar 0,271 yang berarti lebih dari 0,05 . Hal ini menunjukkan bahwa variabel NPM tidak berpengaruh terhadap pertumbuhan laba. Artinya jika NPM mengalami kenaikan, maka pertumbuhan laba tidak mengalami kenaikan.

Hasil penelitian ini mendukung penelitian sebelumnya yang dilakukan oleh Napitupulu (2019) yang menyatakan bahwa tidak adanya pengaruh NPM terhadap pertumbuhan laba. Namun berbeda dengan penelitian Bionda dan Mahdar (2017) yang menyebutkan bahwa Net Profit Margin mempunyai pengaruh terhadap pertumbuhan laba. Maka, hipotesis yang menyatakan bahwa variabel Net Profit Margin (NPM) berpengaruh terhadap pertumbuhan laba tidak dapat diterima.

\subsubsection{Pengaruh Return On Investment terhadap Pertumbuhan Laba}

Hipotesis keempat yang diajukan dalam penelitian ini yaitu variabel Return On Investment (ROI) berpengaruh terhadap pertumbuhan laba. Dari hasil penelitian yang diperoleh, diketahui bahwa Retuen On Investment (ROI) memilikin t hitung sebesar 2,733 dan nilai signifikan sebesar 0,009 yang berarti lebih dari 0,05. Hal ini menunjukkan bahwa variabel ROI berpengaruh terhadap pertumbuhan laba.

Hasil penelitian ini mendukung penelitian sebelumnya yang dilakukan oleh Silalahi (2019) yang menyebutkan bahwa Return On Investment mempunyai pengaruh terhadap pertumbuhan laba. Maka, hipotesis yang menyatakan bahwa variabel Return On Investment (ROI) berpengaruh terhadap pertumbuhan laba dapat diterima.

\section{Kesimpulan}

Berdasarkan hasil analisis data dan pembahasan yang telah dilakukan, maka dapat disimpulkan bahwa :

1. Dari keempat variabel yang meliputi Quick Ratio (QR), Debt to Equity Ratio (DER), Net Profit Margin (NPM), dan Return On Investment (ROI) yang diduga berpengaruh terhadap pertumbuhan laba, ternyata hanya terdapat satu variabel yang berpengaruh terhadap pertumbuhan laba. Variabel itu yaitu Return On Investment. Sedangkan tiga variabel yang lain terbukti tidak berpengaruh terhadap pertumbuhan laba.

2. Dari hasil uji t yang telah dilakukan, dapat diketahui bahwa variabel $\mathrm{ROI}$ merupakan variabel yang paling berpengaruh signifikan terhadap pertumbuhan laba. Hal ini dapat 
diketahui dari nilai signifikansi ROI 0,009 yang merupakan nilai signifikansi terkecil dari independen yang lain.

3. Dari hasil Uji F terbukti bahwa secara serentak (simultan) semua variabel independen berpengaruh signifikan terhadap pertumbuhan laba. Hal tersebut dapat dilihat dari perhitungan SPSS yang menghasilkan nilai signifikansi $F$ yaitu sebesar 0,000 yang berarti lebih kecil dari 0,05.

4. Keseluruhan variabel independen dalam penelitian ini menyumbang sebesar $64,1 \%$ seperti terlihat pada nilai Adjusted $\mathrm{R}^{2}$. Artinya masih terdapat 35,9\% faktor - faktor lain yang belum diketahui dan diteliti secara ilmiah yang dapat mempengaruhi pertumbuhan laba.

a. Keterbatasan Penelitian

Penelitian ini tidak terlepas dari keterbatsan - keterbatasan yang antara lain disebabkan oleh :

1. Dalam penelitian ini hanya digunakan sampel perusahaan makanan dan minuman yang terdaftar di BEl. Hal ini tidak dapat mewakili keadaan seluruh perusahaan yang terdaftar di BEl. Elemen - elemen laporan keuangan yang tidak sama dan perbedaan dalam kegiatan usaha akan berpengaruh pada perhitungan perubahan rasio keuangan dan pertumbuhan laba.

2. Periode penelitian yang diamati terbatas karena hanya mencakup tahun $2015-2018$ (4tahun).

3. Penulis melakukan pengamataan terhadap pertumbuhan laba hanya dengan menggunakan rasio keuangan dengan mengabaikan faktor - faktor lain yang dapat mempengaruhi pertumbuhan laba. Adapun rasio yang menjadi fokus pada penelitian ini adalah Quick Ratio (QR), Debt to Equity Ratio (DER), Net Profit Margin (NPM), danm Return On Investment (ROI).

b. Saran

Berdasarkan kesimpulan diatas, maka penulis dapat memberikan saran sebagai berikut :

1) Bagi Perusahaan

Pada penelitian ini Return On Investment (ROI) memiliki pengaruh yang signifikan 
terhadap pertumbuhan laba, dimana jika ROI naik maka pertumbuhan laba juga akan naik. Jadi, disini perusahaan disarankan untuk melakukan hal - hal yang dapat meningkatkan investasi perusahaan, seperti menarik investor untuk berinvestasi.

2) Bagi Investor

Laba merupakan salah satu tolak ukur yang biasanya kita lihat dari suatu perusahaan, apakah sukses atau tidaknya perusahaan cenderung dilihat dari bagaimana laba perusahaan tersebut. Para investor harus jeli dalam hal seperti ini, termaksud faktor apa saja yang akan mempengaruhi laba dimasa yang akan datang, dengan menganalisis rasio keuangan dapat memberikan gambaran bagi para calon investor dalam mengambil keputusan untuk investasi.

3) Penelitian Berikutnya

Bagi penelitian selanjutnya diharapkan menambah jumlah sampel, variabel, dan periode penelitian yang digumakan dalam penelitian ini agar hasilnya lebih akurat untuk mewakili kondisi perusahaan yang sedang diteliti.

\section{Daftar Pustaka}

Halim, M.M. 2009. Analisis Laporan Keuangan. Edisi Keempat. Yogyakarta: UPP STIM YKPN. Hanafi, M.M., dan A. Halim. 2016. Analisis Laporan Keuangan. Edisi Kelima. Yogyakarta: UPP STIM YKPN.

Harahap, S. 2012. Analisis Kritis atas Laporan Keuangan. Jakarta: Rajawali Pres.

Kasmir. 2008. Manajemen Perbankan. Jakarta: PT. Raja Grafindo Persada.

Khalidazia, I.K., dan I. Muda. 2014. The Influence of Profitability And Liquidity Ratios on The Growth of Profit of Manufacturing Companies a Study of Food and Beverages Sector Companies Listed on Indonesia Stock Exchange. International Journal of Economics, Commerce and Management 2(12): 1-17.

Mahendra, A.S. 2017. The Impact Of Financial Ratio on Ability to Predict Profit : An Empirical Study In Manufacturing Of Food And Beverage Sub Sector. International Journal of Research in Business, Economics And Management 1(1): 27-45.

Mardi, I., I.A. Nasir, dan Y.M. Basri. 2012. Pengaruh Rasio Keuangan Terhadap Pertumbuhan Laba Pada Perusahaan Asuransi yang Terdaftar di Bursa Efek Indonesia Tahun 2007 2011. Jurnal Universitas Negeri Riau.

Napitupulu, R.D. 2019. Determinasi Rasio Likuiditas dan Rasio Profitabilitas Terhadap Pertumbuhan Laba Pada Perusahaan yang Terdaftar di BEI. Journal of Information System, Applied, Management, Accounting, and Research 3(2): 115-120 .

Sayekti, S., dan S. Saputra. 2015. Analisis Pengaruh Rasio Keuangan Terhadap Pertumbuhan Laba Pada Industri Rokok Yang Terdaftar di Bursa Efek Indonesia. Jurnal Ekonomi dan Kewirausahaan 15:115-121.

Siagian, M.Y. 2005. Aplikasi Supply Chain Management dalam Dunia Bisnis. Edisi kesatu. Jakarta: Grasindo Cikal Sakti.

Silalahi, C.S. 2019. Analisis Rasio Keuangan Dalam Memprediksi Perubahan Laba Pada Perusahaan Manufaktur Yang Terdaftar di Bursa Efek Indonesia (BEI). Jurnal Reviu Akuntansi dan Keuangan 2(1): 35-62.

Sugiyono. 2013. Metode Penelitian Bisnis. Bandung: Alfabeta. 
Taruh, V. 2011. Analisis Rasio Keuangan dalam Memprediksi Pertumbuhan Laba Pada Perusahaan Real Estate dan Property di Bursa Efek Indonesia (BEI) dan Singapura (SGX). The Indonesian Accounting Review 2(1): 155-178. 